\title{
Hegemony, National Allegory, Exile: The Poetry of Shirley Lim
}

In Imagined Communities: Reflections on the Origin and Spread of Nationalism, Anderson makes the point that "nation-ness is the most universally legitimate value in the

political life of our time” ${ }^{11}$. Indeed, the idea of the nation is universally legitimate not only in the political life, but also in the everyday life of its people. After all, the nation is a discursive site where networks of social, political, cultural and ideological processes flourish, intertwine and dwindle. One may go so far as to say that the assumptions we hold as human beings are the assumptions we hold as citizens of a particular nation. These assumptions - influenced by history, geography and economics - bind disparate individuals into a community. With these considerations in mind, Anderson describes the nation as an "imagined community". The nation, Anderson argues, is "imagined because the members of even the smallest nation will never know most of their fellow-members ... yet in the minds of each lives the image of their communion”2

Yet what happens when the political imaginary circumscribes a space untenable and inhospitable to certain members of its society? What happens when the political elites of a nation, in the name of nationalism, promote and legitimise one way of life and marginalize others? Bernard Wilson points to one specific plight of being marginalized in “Memory, Myth, Exile: The Desire for Malaysian Belonging in K. S. Maniam’s The Return, 'Haunting the Tiger' and In a Far Country" by examining the condition of internal exile articulated in Maniam's works ${ }^{3}$. I would like to explore in this essay the works of another writer that represent a different kind of response to being marginalized by the nation. After having left Malaysia and rejected its state ideology, Shirley Geok-lin 
Lim, who regards herself as a voluntary exile, has a successful career as a poet, novelist, academic and critic. Instead of expressing the desire for national belonging, as Maniam's writings do, Lim's works exemplify a poetics of liberation, one that articulates a selfhood that renders the strictures of a nation-bound identity irrelevant.

\section{National Hegemony}

Up till today, the dominant political ideology in Malaysia is that of Malay nationalism. Its hold on the nation was challenged only once in recent history during the general elections of 10 May 1969. As reported by Gordon P. Means, when the elections indicated the erosion of Malay supremacy in the political arena, the race riots that occurred three days later on 13 May 1969 necessitated the declaration of a state of Emergency ${ }^{4}$. This was followed by a series of political stratagems that re-established Malay sovereignty in Malaysia, culminating in the declaration of the Rukunegara, the national ideology of Malaysia, on 31 August 1970. The declaration asserts, among other things, that

It is the duty of a citizen to respect and appreciate the letter, the spirit, and the historical background of the Constitution. This historical background led to such provisions as those regarding the position of ... the Rulers, the position of Islam as the official religion, the position of Malays and other Natives, the legitimate interests of the other communities, and the conferment of citizenship. It is the sacred duty of a citizen to defend and uphold the Constitution. ${ }^{5}$

One need only note the centrality of Islam and Malay in the above declaration. In the declaration, non-Muslim or non-Malay are given the status of "others"; they are "other Natives" and "other communities". Thus, the Rukunegara relegates its others, namely, the Chinese, Indian and Eurasian communities, to the status of second-class citizenship, even though in 1964, as Means points out, they constituted 54.1 per cent of the population ${ }^{6}$. 
The Rukunegara is further legitimised by constitutional amendments, which decreed that "the powers and status of the Malay Rulers; citizenship rights of nonMalays; Malay special rights and privileges; the status of Islam as the official religion; and the status of Malay as the sole National Language” are issues prohibited from public interrogation $^{7}$. In short, the declaration denies the right of non-Malays to question the authority and prevalence of Malay hegemony. In Malaysia, civic and national participation hinge upon acceptance of these decrees. Many commentators have indicated that there is in Malaysian political discourse a "trend towards authoritarian rule" ${ }^{8}$. This is especially evident in its language policies. Malay was gradually used as the only language of instruction in secondary schools and universities since 1971, although on utilitarian grounds, English is now being used in certain subjects in the latter since the $1990 s^{9}$

Malay nationalism constitutes a form of cultural hegemony that governs not only the social and political arena, but also the formation of a literary canon. Mohamed Taib Osman writes with the decree of the Malay nationalist ideology when he claims "(i)t is without doubt that the literature in Malay is the most logical choice to provide the foundation for the further development of National Malaysian literature»10. Muhammad Haji Salleh asserts likewise when he writes that "in Malaysia ... the return to Malay ... is

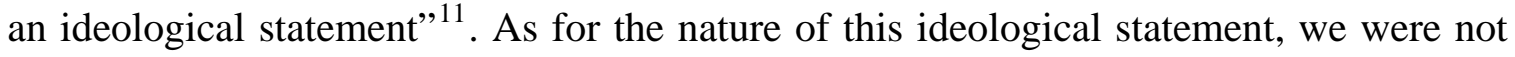
told, though one might hazard a guess. One may argue that the privileging of the Malay language over English is not aimed directly at inhibiting the efforts of non-Malay writers, but is an anti-colonialist gesture inherent in Malaysian nationalism. 
However, the forces of colonial occupation have long since retreated from Malaysia. Thus whatever anti-colonialist sentiments persisting are geared only towards resisting the legacies of imperialism, one of which is the English language. Yet this resistance produces exclusion, disregarding the literature of non-Malay writers writing in English. A case in point: when one peruses a publication entitled An Anthology of Contemporary Malaysian Literature (1988), one expects that works written by Malaysian writers, regardless of ethnicity, be represented. One expects, for instance, selections from novels or short stories by K. S. Maniam and Lee Kok Liang. Or it would not be too much to expect a selection of poems by Wong Phui Nam. After all, they are contemporary as well as Malaysian. Yet in his preface, Muhammad Haji Salleh informs us that "This anthology is an attempt to gather the best from contemporary Malaysian literature in English translation” ${ }^{12}$. If so, the anthology should rightly have been entitled An Anthology of Contemporary Malaysian Literature in Translation. Better yet, An Anthology of Contemporary Malay Literature in Translation. The omission of the words "in translation" and the substitution of "Malay" with "Malaysian" deliver the subtle implication that the best contemporary Malaysian literature is written only in the Malay language and has to be translated. Or worse - it implies that Malaysian literature is written only in Malay. It is obvious from the table of contents, which lists only the names of Malay writers, and the introduction that follows, which discusses only the history of Malay literature, that Muhammad Haji Salleh writes with the assumption that the best of contemporary Malaysian literature is and can only be literature written in Malay and that literature written in other languages do not exist. 
Indeed, one would not have realised that Malaysia is a multicultural society if one were to survey its national literature. It is official policy that non-Malay writers who do not write in Bahasa Malaysia, the official national language of Malaysia, are excluded from the body of texts known as "National Literature", and are grouped under the term "Sectional Literatures" ${ }^{13}$. We can only conclude that with the retreat of British imperialism from Malaysia, one form of cultural hegemony is substituted for another. In the name of national interest, the literature of non-Malay writers writing in English and other languages is deprived of national recognition.

“One group’s empowerment”, Lim writes, “appeared to lead to another's oppression” ${ }^{14}$. Lim is a Peranakan who left Malacca after the race riots of 13 May 1969. In her afterword to Monsoon History: Selected Poems, Lim, who now holds American citizenship, refers to the phrase "voluntary exile" as "one of those remarkable ironies of the modern political consciousness, where one denies the reality of state aggression by positing the individual's power to escape or circumvent it”" ${ }^{\prime 1}$. Indeed, how voluntary is voluntary exile? It is true that the Chinese population in Malaysia continues to thrive especially in areas of business. It is also true that ever since the race riots of 1969, there are no major occurrences of organised violence against the non-Malay communities in Malaysia. It is also true that there is a distinction to be made between emigration and exile. However, one need not be held at gunpoint to know that one is being oppressed. In a nation where the distributions of wealth and university student quotas are based on criterion of race, one knows that injustice is involved.

"In claiming exile”, Lim informs us, "the individual is crying foul against a state; is asserting a condition of inequality and injustice at the hand of an oppressing force” ${ }^{\text {. }}$. 
Voluntary exile, paradoxically, is compelled, as when Malaysian politics becomes increasingly dominated by a Malay nationalist ideology that discriminates against members of other races and cultures. If Lim is an exile because she stands outside cultural, linguistic and political boundaries erected by Malay nationalism, then one may propose that as a strategy of articulation, her poetry produces a national allegory that interrogates these contextual boundaries.

\section{Poetry as National Allegory}

In "Third-World Literature in the Era of Multinational Capitalism”, Fredric Jameson suggests that "(a)ll third-world texts are necessarily ... to be read as ... national allegories" [his emphasis] ${ }^{17}$. One may object, as Aijaz Ahmad has done, to Jameson's presumptuous use of the term "necessarily", for it restricts the range of interpretive possibilities for the third-world text ${ }^{18}$. However, Jameson is cautious in his use of the term "third-world". He employs the term rather loosely - acknowledging the want of a better term - to describe non-western countries, and is mindful of the fact that it "obliterates profound differences between a whole range of non-western countries and situations” ${ }^{19}$. Despite this, Ahmad protests that Jameson's recommendation amounts to a reductive "privileging of the nationalist ideology" in the treatment of emergent literatures ${ }^{20}$.

In his reply to Ahmad, Jameson makes the point that a national allegory need not necessarily possess a nationalist agenda. "The concept of 'national allegory”, Jameson argues, "was not meant as an endorsement of nationalism" ${ }^{21}$. As a political discourse, agents of nationalism construct a coherent and unified identity that purports to be 
different from that of other nations. Ideological boundaries are set up to establish what is intrinsic and extrinsic to this national identity, often to the extent that narratives heterogeneous to the construct are denied. When Jameson recommends that third-world texts be read as national allegories, he is suggesting that we examine the impact of nationalism on the individual. He points out that "the story of the private individual destiny is always an allegory of the embattled situation of the public third-world culture and society" [his emphasis] ${ }^{22}$. In other words, when read as national allegory, the text reveals the experience of the individual as a function of the cultural and political exigencies within a society. A national allegory, Jameson argues, need not be nationalist; rather, it is also able to depict the cultural and political struggles within a society as a protest against an oppressive form of nationalism.

One wonders whether Jameson and Ahmad may have misunderstood each other, for it seems like they are writing at cross-purposes. Ahmad's point is that “Third World Literature" (as he points out, this is itself a problematic term) need not be read with the nation as the sole analytic category, while Jameson's defence is that the term "nation" as he uses it is not synonymous with "nationalism". In any case, I find it useful to read Lim's poetry with reference to the concepts of nation and nationalism, as clearly, her experiences point us towards the consequences both has for her identity. Her memoirs and many critical essays have also highlighted the nation as an analytic category for her lived experience and her poetry. It is also worthwhile to note that Jameson's recommendation of reading the text as national allegories finds support in Koh Tai Ann's notion of poetry as fictional autobiography. Koh argues that

Lim's characteristic habit of ordering her poems in significant sections (or re-ordering them, as in the case of Modern Secrets), invites the reader to 
see each section as stations along a personal journey or as the major preoccupations of a poetic life. In either case, the impression is of poetry as fictional autobiography. ${ }^{23}$

An autobiography is fictional in the sense that while the narrated experience of the persona is to some extent a product of the imagination, the contextual exigencies of which the individual experience is a function is historically legitimate. If both strategies of articulation seem identical, it is because they advocate the reading of texts as functions of the contexts in which they are written. Read as national allegory, Lim's poetry uncovers the political exigencies of her birth country. As fictional autobiography, her poems are functions of the poet's particular exilic experiences. Lim's poetry is thus a site for articulating the personal against the political. Furthermore, there is no doubt that her poems demand to be read in relation to the nation as an analytic category. This is nowhere more apparent than in “Song of an Old Malayan”, where Lim writes:

Will you sell me, also, down the river of nationalism, my sometime brother, who know your accent, can speak your poetry?

Your family and mine, croaking, drank from the same well.

Now you are grown rich [...]

Shall I sink silently to the stream's muddy bottom while gold flecks rise to your hands like scum?

But you need me, my brother. How else to find thorn of martyrdom, rose of the east, your history's self? ${ }^{24}$

Read as national allegory, Lim's poem becomes a site of dissension. It registers a bitter reaction against Malaysia's nationalist agenda, suggesting that through the process of disavowal that national identity is created. As the poem suggests, that disavowal has to be forever enacted so as to reinstate a dominant ideology, identity or selfhood. "But you need me, my brother”, the persona protests, for she is also part of the "history's self”. Martyrs are needed just as exiles are needed to assert a nation's identity. Thus needed 
only as an outsider, Lim finds herself the victim of the process of negative nationalism, whereby identity is founded on exclusion.

The next question one might ask is, is this a necessary condition? Need nationalism always be based on exclusion? We need look no further than to Malaysia's closest neighbour to realise that this need not be so. If anything, Singaporean nationalism is based on inclusiveness (some would say too inclusive as to include what is now called “foreign talent”) more than anything else. One may even say that Singapore’s status as a sovereign state is also a function of Malaysia's exclusive nationality. One of the reasons for Singapore being ejected from the Federation of Malaya in 1965 after the 1963 merger is that Singapore has a population consisting of a Chinese majority, which would upset significantly the racial composition the Malay government has in mind. Also, the fact that Lee Kuan Yew’s political party was seriously campaigning for a "Malaysian Malaysia" rather than "Malay Malaysia" disguised as the former would give the Malay politicians in Kuala Lumpur some pause. Nationalism need not necessarily be based on exclusion, as the case of Singapore has shown.

\section{Reclaiming Home, Language, Race}

The political aggression of the state, which led to Lim's exile, does not imply that she must cut off all ties from their homeland. Lim's poetry demonstrates that the exile, as described by Edward Said, "exists in a median state, neither completely at one with the new setting nor fully disencumbered of the old, beset with half-involvements and halfdetachments, nostalgic and sentimental”25. Despite geographic displacement, Lim 
maintains ties to her homeland through kinship. "Bless me, spirits, I am returning”, writes Lim in "Bukit China":

Country is important,

Is important. This knowledge I know

If it will rise with smoke, with the dead.

He did not live for my returning.

News came after burial.

I did not put on straw, black,

Gunny-sack, have not fastened

Grief on shoulder, walked mourning

Behind, pouring grief before him.

Not submitted to his heart. ${ }^{26}$

“Bukit China” carries the insight that one needs no political sanction to write of one's homeland. The title of the poem, borrowed from the name of the largest Chinese cemetery in Malacca, is invested with cultural significance. The persona reclaims her cultural landscape through an invocation that appeals to ethnic and cultural ancestry "Bless me, spirits, I am returning" - with the awareness that canonical, political and geographical boundaries are, at best, ideological constructs. As Lim puts it, “(s)omeone who walks between and in and out of national and institutional borders draws attention to the arbitrariness of divisions and to the vested interests of gatekeepers”27.

In Lim's poetry, home is often depicted as a thing of the past, accessible only through infrequent visits, dreams and memories. The home becomes a site of nostalgia, as in the case of "Monsoon History":

Drinking milo, Nonya and baba sit at home.

This was forty years ago.

Sarong-wrapped they counted

Silver paper for the dead.

Portraits of grandfathers

Hung always in the parlour. ${ }^{28}$ 
In the above domestic scene, cultural signifiers such as sarongs, offerings for the deceased, and portraits of ancestors confer a distinct Peranakan identity to the inhabitants. However, this is not a scene of the present, but of the past, as re-emphasised at the end of the poem: "This was forty years ago, / When nyonya married baba" 29 .

One of the reasons for Lim's poetry being barred from national recognition is that she writes in English. It is interesting to note in Lim's poems that there is not only the affirmation of familiarity with one's native landscape, but also the affirmation of a familiarity with the language one employs to depict one's native landscape. Anne Brewster comments that in the case of Malaysian poetry written in English, "the motive for 'naming' the landscape arose not from the need to explain aspects of the environment

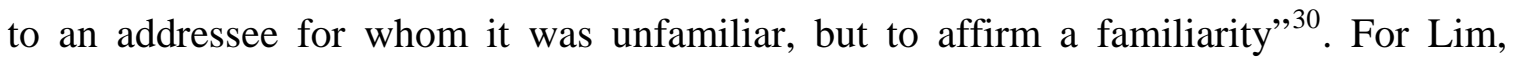
language was never a matter of choice. In a semi-autobiographical essay, she asserts that her "first memory of spoken language is also [her] first memory of the English language ... for [her], if not for other Malaysians of [her] generation, English was [her] mother tongue”31. Lim's allegiance to the language is articulated in "Lament”:

I have been faithful

Only to you, My language. I choose you Before country ${ }^{32}$

However, Lim does not employ the language uncritically. In another essay entitled “Chinese Ba / British Da: Daughterhood as Schizophrenia”, Lim writes of the necessity of having to negotiate between two fathers, and by extension, two cultural-linguistic paradigms -- the British Empire that provided her with a colonial education, and her biological Chinese father with his "Hokkien patriarchal privilege"33. 
As such, Lim is aware of the cross-cultural implications involved in the use of the English language. We see this exemplified in "Learning English”, where she writes that the use of the language "wasn’t like changing / shoes”, rather, it involves "learning / to let go and to hold on” ${ }^{34}$. The poem betrays Lim's awareness of having to interrogate the cultural assumptions of the English language in order to depict her native homeland. In "Monsoon History", the poem we have seen earlier, one detects the sharp juxtaposition between English culture and her native homeland as the persona is

Reading Tennyson, at six

p.m. in pajamas, Listening to down-pouring rain: the air ticks With gnats, black spiders fly, Moths sweep out of our rooms Where termites built their hills of eggs and queens zoom In heat. $^{35}$

Lim negotiates between language and the native landscape in such a way that, to use the words of Edwin Thumboo, "the language is remade, where necessary, by adjusting the interior landscape of words in order to explore and meditate the permutations of another culture and environment” ${ }^{36}$.

Thus, by appropriating the language of the British metropolitan centre and subjecting it to a negotiation with the physical landscapes of Malaysia, Lim effaces the boundary between the ex-coloniser and the formerly colonised, and this is the boundary that the Malay nationalists seek to erect when they reject literatures written in English from the national canon. The authors of The Empire Writes Back argue that "the discussion of post-colonial writing ... is largely a discussion of the process by which the language, with its power, and the writing, with its signification of authority, has been 
wrestled from the dominant European culture" ${ }^{37}$. It follows that when Lim's poems are read as national allegories, the linguistic boundary as a delineation of power between the ex-coloniser and the previously colonised is effaced. Thus, as in the case of Caliban, language is appropriated from the British metropolitan centre for one's own articulation.

The appropriation of language from the British metropolitan centre is also an act of defiance against the cultural and social order prescribed by Malay nationalism. As Lim puts it:

I have seen myself not so much as sucking at the teat of British colonial culture as actively appropriating those aspects of it that I needed to escape that other familial/gender/native culture that violently hammered out only one shape for self. ${ }^{38}$

However, while writers of former colonies do not reject the English language as the medium of literary production, one may say that they are aware of their liminal status as users of the language. "The non-English writer who writes in English”, the Malaysian poet Wong Phui Nam informs us, is "a miscegenated being, very much and yet not an heir to the tradition of Shakespeare and Milton”39. The plight of non-English writers who write in English, indeed, their non-canonical status, reminds us that there are cultural centres other than that of the British metropolitan.

The need to mediate the English language with native landscapes to efface the boundary between the ex-coloniser and the previously colonised, and the subsequent effacing of the canonical boundary set up by the Malay nationalists reveal the poets as products of intricate historical and political exigencies. No less important to our discussion is the way Lim calls attention to the fact that there are ways of constructing one's identity other than via an appeal to one's racial ancestry. There is an acknowledgement here that although she of Chinese descent, she is unable to completely 
align herself to the heritage of Chinese poetry for racial-linguistic continuity. This can be seen in "To Li Poh" ${ }^{40}$, where Lim writes:

I read you in a stranger's tongue, Brother whose eyes were slanted also.

But you never left to live among Foreign devils. Seeing the rice you ate grow In your own backyard, you stayed on narrow Village paths. Only your mind travelled Easily: east, north, south and west Compassed in observation of field And family. All men were guests To one who knew traditions, the best Of race. Country man, you believed to be Chinese No more than a condition of human history. Yet I cannot speak your tongue with ease, No longer from China. Your stories Stir griefs of dispersion and find Me in simplicity of kin. ${ }^{41}$

Lim's attitude to Li Po, and by extension, to the canon of Chinese classical poetry, is ambivalent. On the one hand, the poem betrays a sense of estrangement from the classical canon when the persona acknowledges her inability to speak the language "with ease" and has to read Li Po's poems in translation. On the other hand, she claims the heritage "in simplicity of kin", on grounds of racial descent. The ambivalence comes with the knowledge that Li Po wrote in a very different time and place, constrained like any other writers by his own social-historical context. While Li Po is depicted as a poet who stays on "narrow / Village paths" and is comfortably situated within Chinese culture, Lim is a Peranakan who left her native homeland and is now an American citizen. Her social circumstances are vastly different from those of Li Po, and she writes with the understanding that her identity has to be negotiated between cultures. Also, it has to be pointed out that Lim's attempt at recovering her Chinese classical heritage through her 
poetry is somewhat limited, having in this instance employed stereotyped attributes such as slanted eyes as a signifier of Chinese culture.

\section{Trans-national Feminism}

As a metropolitan Asian-American, Lim negotiates among several cultures in the world outside the boundaries of home. One sees this in "Visiting Malacca", where the persona

comments that she is "losing / Ability to make [herself] at home"42. In "Dedicated to Confucius Plaza”, the domestic space is conflated with images outside of home as an expression of Lim’s Asian-American identity:

I live in a small house

On top of fifty other houses.

Every morning I face the East River

Where the air is cold as

On Tung Shen Mountains.

The mountains are made of loess

Brought down by the Yang-tze.

This city is a mountain

Also, made of Asia,

Europe and Africa.

They call it America. ${ }^{43}$

The persona is particularly sensitive to racial and cultural boundaries, and comments at the end of the poem that "(i)t is not hard to be / An Asian-American Chinee"44. The deliberate misspelling indicates, of course, that it is difficult for her to appeal to an essentialist identity, to identity herself as Chinese. The persona is aware of her self as being composed of a plurality of cultural identities. We see the domestic space as a projection of America, composed of sharp juxtapositions between Asia, Europe and Africa. Also, there is no longer a clear delineation between what is at home and what is out there in the rest of the world. Rather, the external world defines the home, thus 
eroding the boundary that separates the private from the public. Perhaps it is the logic of Lim's exilic condition that she can never inhabit a domestic space that is truly private. This condition is allegorically rendered in "House-Hunting", where the persona searches unsuccessfully for a perfect home. At the beginning of the poem, the persona declares, "(w)e were looking for something. / For a year we searched the house" ${ }^{45}$. However, at the end of the poem, she realises that the search is futile, for the "high ceilings will out-wait us. / When we go, someone else will look for it” ${ }^{36}$.

In the collections of poems written prior to the publication of What the Fortune Teller Didn't Say in 1998, Lim's antipathy towards American culture is overt. This is exemplified in poems such as "To Marianne Moore”, “An Immigrant Looks at Walt Whitman" and "I Defy You”. In "I Defy You” for example, she challenges Wallace Stevens “to prove 'the exquisite truth", and points out that for the "young Cambodian whose father drowned", Stevens is "an American fiction" ${ }^{47}$. The poems in What the Fortune Teller Didn't Say, however, testify to Lim's gradual assimilation into American culture. Lim is committed to the feminist cause, and American feminism for her "promises a community that paradoxically is constructed not on commonality but on difference" ${ }^{\text {48 }}$. We see this expressed in "Learning to Love America” where the persona proclaims that she is becoming more comfortable in America, being able to "say we rather than they" ${ }^{49}$. However, the ambivalence of her cultural identity is still a prevailing concern, as when the persona sees her son's “eyes redden when he is asked who he is / ... [and] he answers I don't know"50.

Clearly, Lim does not have the luxury of being completely situated within a particular canon of literature, whether Malaysian (though it is her birth country), British 
(though she writes in English), or Chinese (though she is Chinese), and is thus bereft of a cultural identity from which to write. The personae are always hybrid, composed of not one identity but many. In "Modern Secrets" for example, the self is depicted as being fragmented as she negotiates between the American context and her racial identity:

Last night I dreamt in Chinese.

Eating Yankee shredded wheat

I said it in English

To a friend who answered

In monosyllables:

All of which I understood. ${ }^{51}$

In the first three lines of the poem, one detects a sharp disjunction between the language of the dream and the language in which the retelling of dream takes place: the dream occurs in Chinese while the persona retells it in English. The self in Lim's poetry is fragmented between different cultures as a result of the poet's particular exilic experiences, and this implies that she is in a position to identify with women of different social, economic and cultural backgrounds who are equally marginalized by fact of their race and gender. Thus, Lim's marginality becomes a site from which she forges a community of women. In her memoirs, Lim writes that “(i)t's true that women are divided by unequal privileges of race, class, age, nation ... but across these divisions ... a rare yet common ground is visible" ${ }^{32}$.

She treads this common ground by first employing the female body in her poetry as a site of articulation. In "In Defence of the Crooked", the persona describes her body as follows:

Mouth dragged down to the side; Breast lumpier than the other. One rib bone curves high and hangs To the west. My teeth stagger 
To catch on celery strings

And tongue. Nervous, I stutter.

The last toe and companion curl

Like callouses. I bowl into gutters.

Therefore, I don't trust straight things ${ }^{53}$

If Lim's poetry is preoccupied with depicting the flawed body, it is because the perfect body is, more often than not, a fiction. By employing the body as a site of articulation, Lim is able to identify with other women whose bodies are physically inflicted by patriarchal violence. In "Pantoun for Chinese Women" for example, Lim writes of the phenomenon of female infanticide in China as an indictment of the cultural bias against women. The poem protests against the way the body of a female infant is reduced to ashes, simply because it is said that "a child with two mouths is no good" ${ }^{54}$.

The female body is depicted likewise as the site of colonial violence. In "Returning to the Missionary School", the colonial education experienced by Lim as a convent student in Malaysia during the height of British imperialism is revealed to be complicit with patriarchal oppression in its representation of women. Colonial education taught "(s)imple natives [to] believe in / Breastless women stuffed with God”55. The oppression is revealed to be working in two ways: firstly, the sexual identity of women is a knowledge denied to the native female, and secondly, the sexual identity of women belonging to the culture of the ex-coloniser is likewise suppressed. Women in both the formerly colonised and the colonising culture suffer the same history of oppression under the process of imperialism, and it is by depicting this common history through the politics of the body that Lim's poetry effaces the boundary between the colonised native women and their female cultural Other(s). As Lim puts it, “(w)e understand each other in devious 
ways [because of] our physical desires and the shame we have been trained to feel over our bodies" $" 56$.

Perhaps it is because of the history of patriarchal and colonial violence that has been inscribed onto the female body that a feminist poetics, which depicts a matriarchal lineage, is both a necessity and an impossibility. In her memoirs, Lim writes that

we need to reconsider Virginia Woolf's plea that women think back through their mothers. For many of us, it is the story of our mothers that makes a female heroic so necessary, yet also so impossible. ${ }^{57}$

If the female heroic is impossible, she says, it is because a woman "continues to be constituted by a Male Other. When [they] look at [themselves] in maturity, the gaze [they] have re-constituted from [their] culture is Male" ${ }^{38}$. Thus, one may say that it is from the perspective of Asian feminism that Lim's poetic and critical agenda becomes one and the same. In "Inventing Mothers", Lim seeks to retrace the sensuality of her cultural roots through the bodies of mothers, yet the sensuality is tainted by the knowledge that Asian societies are oppressive in their prescription of female roles:

I peeked at them buried in hearts of houses, flapping, like hearts that will not fail, spare, efficient hands at pots and foreheads, at thread and lots

of mending, heaps of broken promises from the world, shattered china cups, and fathers' thrashings. They were not brusque like brothers or miserly like old aunts. They made breakfasts, washed, swept, and stayed

till next morning. A little friend's prayerful mother was gaunt bone, mean. It didn't matter. She blanched cheeks, trained waist and hair, made ends meet where nothing else would. She 


$$
\text { put herself before misery }{ }^{59}
$$

The bodies of mothers are depicted as functioning for the male. They are first subjected to their "fathers' thrashings". When they are of marriageable age, their bodies are “trained in waist and hair”. After giving birth to children, their bodies are taught to be “efficient hands at pots / and foreheads”. The houses they reside in are not even theirs. The mothers “made breakfasts, washed, swept, and stayed / till next morning”. They are relegated to the roles of servants, and are outsiders in their own home. The poem reconstructs the female body as a site of patriarchal subjugation precisely as a protest against the restrictive roles created for women.

Thus in her poetry, Lim protests against oppressive representation by patriarchy and colonialism. As an Asian-American woman, Lim's identity is liminal as she is doubly marginalized by race and gender. Thus she is able to write on behalf of women of other cultures who are in equally marginal positions. It is interesting to note that her poetry betrays an alignment with metropolitan feminism. It is not the case that Lim positions herself as an American or British feminist, but that her poetry is fuelled by the very same urgencies that propelled these feminisms. In her memoirs and works of literary criticism, she often writes of Asian women as being doubly oppressed by patriarchy and by colonialism. Consider the following statements:

While sex as intercourse may or may not be repressed in many Asian societies, the body itself, especially the female body, is socialized to be nonexpressive of its sexuality. ${ }^{60}$

In order for the woman to write in this doubly colonial world, the self must be in exile; she has to leave the rule of her community and become, if only in her writing, undomesticated, wild. Thus I begin with myself as the feral child. ${ }^{61}$ 
Feminism as embodied in Lim's poetry is conflated with her exilic conditions. The politics of the body that characterises her poetry interrogates the racial, social and economic boundaries between women. "So I have permission to speak", Lim writes,

but permission to speak as and for a minority; not as an individual which is an ideologically majority construct in the United States, but as a representation of a minoritism of specified color and race. [emphasis hers] ${ }^{62}$

For Lim, "recognizing a material self is to begin to write politically, with a sense of history and larger forces at work outside the subject" ${ }^{\circ 3}$. Her poetry portrays the female body, regardless of race and class, as having been victimised by patriarchal and colonial discourses. In this respect, her poetry testifies to Hélène Cixous' assertion that “( $t$ )here always remains in woman that force which produces/is produced by the other -- in particular, the other woman” ${ }^{\prime 64}$. Perhaps it is not too far to say that for Lim, nationality has been displaced by what seems to be an eclectic form of Asian feminism.

One may say, then, that the poetry of Lim testifies to cultural hybridity out of the liminal spaces from where she writes. Having been estranged from her nation by an exclusive nationalism, Lim demonstrates that one may utilise the liminal or exilic condition as a condition from which to articulate and affirm identities against hegemonic coercion. As Homi Bhabha points out, we need to

focus on those moments or processes that are produced in the articulation of cultural differences. These 'in-between' spaces provide the terrain for elaborating strategies of selfhood ... that initiate new signs of identity ${ }^{65}$

Lim's poetry has much to teach us when it comes to inhabiting a liminal and transnational space. When one is deprived of an indigenous culture from which to write, one then negotiates between different cultures as a strategy of articulation. Lim’s “The Will”, then, may be read as a complementary couplet to Bhabha's above statement: 
There is a will resisting resistance; we inhabit

Those spaces given up by ghosts we disinherit. ${ }^{66}$

\section{Notes}

${ }^{1}$ Benedict Anderson, Imagined Communities: Reflections on the Origin and Spread of Nationalism Revised edition. (London: Verso, 1991), p. 3.

${ }^{2}$ Ibid., p. 9.

3 Bernard Wilson, 'Memory, Myth, Exile: the Desire for Malaysian Belonging in K. S. Maniam's The Return, "Haunting the Tiger” and In A Far Country', Textual Practice, 17:2, (2003), pp. 391-412.

${ }^{4}$ Gordon P. Means, Malaysian Politics: The Second Generation (Singapore: Oxford University Press, 1991), pp. 8-10.

${ }^{5}$ Ibid., p. 13.

${ }^{6}$ Ibid., p. 1.

${ }^{7}$ Ibid., p. 14.

${ }^{8}$ Francis Loh Kok Wah and Khoo Boo Teik, 'Introduction', in Loh and Khoo (eds.) Democracy in Malaysia: Discourses and Practices. (Richmond, Surrey: Curzon Press, 2002), p. 4.

${ }^{9}$ Francis Loh Kok Wah, 'Developmentalism and the Limits of Democratic Discourse', in Loh and Khoo (eds.) Democracy in Malaysia: Discourses and Practices (Richmond, Surrey: Curzon Press, 2002), p. 29.

${ }^{10}$ Mohamed Taib Osman. 'Towards the Development of Malaysia’s National Literature', Tenggara 6 (1973), p. 115.

11 Muhammad Haji Salleh, 'Modernising with Tradition: Directions in Contemporary Southeast Asian Poetry’, Tenggara 24 (1989), p. 3.

12 Muhammad Haji Salleh, 'Preface', in Muhammad Haji Salleh (ed) An Anthology of Contemporary Malaysian Literature (Kuala Lumpur: Dewan Bahasa dan Pustaka, 1988), p. xi.

${ }^{13}$ Lloyd Fernando, Cultures in Conflict: Essays on Literature and the English Language in South East Asia (Singapore: Graham Brash (Pte) Ltd, 1986), p. 138. 
${ }^{14}$ Lim, Shirley Geok-lin, Among the White Moonfaces: Memoirs of a Nyonya Feminist (Singapore: Times Books International, 1996), p. 188.

15 Shirley Geok-lin Lim, Monsoon History: Selected Poems (London: Skoob Books Publishing, 1994), p. 168.

${ }^{16}$ Ibid., p. 167.

17 Fredric Jameson, 'Third-World Literature in the Era of Multinational Capitalism', Social Text 15 (1986), p. 69.

${ }^{18}$ Aijaz Ahmad, 'Jameson’s Rhetoric of Otherness and the "National Allegory”, Social Text 17 (1987), p. 4.

${ }^{19}$ Fredric Jameson, 'Third-World Literature in the Era of Multinational Capitalism', p. 67.

${ }^{20}$ Aijaz Ahmad, ‘Jameson’s Rhetoric of Otherness and the “National Allegory”’, p. 5.

21 Fredric Jameson, ‘A Brief Response’, Social Text 17 (Fall 1987), p. 27.

${ }^{22}$ Fredric Jameson, 'Third-World Literature in the Era of Multinational Capitalism', p. 69.

${ }^{23}$ Koh Tai Ann, 'On the Margin, in Whose Canon? The Situation of Ee Tiang Hong and Shirley Lim', in Anna Rutherford (ed.) From Commonweath to Post-Colonial (Sydney: Dangeroo Press, 1992), p. 128.

${ }^{24}$ Shirley Geok-lin Lim, Modern Secrets (Sydney: Dangeroo Press, 1989), p. 97.

${ }^{25}$ Edward Said, Representations of the Intellectual (London: Vintage, 1994), p. 49.

${ }^{26}$ Shirley Geok-lin Lim, No Man's Grove (Singapore: Department of English Language and Literature, National University of Singapore, 1985), p. 39.

${ }^{27}$ Shirley Geok-lin Lim, Among the White Moonfaces, p. 334.

28 Shirley Geok-lin Lim, Crossing the Peninsula and Other Poems (Kuala Lumpur: Heinemann Educational Books (Asia) Ltd, 1980), p. 90.

${ }^{29}$ Ibid., p. 91.

${ }^{30}$ Anne Brewster, Towards a Semiotic of Post-Colonial Discourse: University Writing in Singapore and Malaysia 1949-1965 (Singapore: Heinemann Asia, 1989), p. 17. 
${ }^{31}$ Shirley Geok-lin Lim, 'The Dispossessing Eye: Reading Wordsworth on the Equatorial Line', in Peter Hyland (ed.) Discharging the Canon: Cross-Cultural Readings in Literature (Singapore: Singapore University Press, 1986), p. 127.

32 Shirley Geok-lin Lim, Modern Secrets, p. 30.

33 Shirley Geok-lin Lim, 'Chinese Ba / British Da: Daughterhood as Schizophrenia', in Shirley Chew and Anna Rutherford (eds.) Unbecoming Daughters of the Empire (Sydney: Dangeroo Press, 1993), p. 142.

${ }^{34}$ Shirley Geok-lin Lim, Monsoon History: Selected Poems, p. xxiii.

${ }^{35}$ Shirley Geok-lin Lim, Crossing the Peninsula and Other Poems, pp. 90-1.

${ }^{36}$ Edwin Thumboo, 'Introduction', in Thumboo (ed.) The Second Tongue: An Anthology of Poetry from Singapore and Malaysia (Singapore: Heinemann Educational Books (Asia) Ltd, 1976), p. ix.

${ }^{37}$ Bill Ashcroft, Gareth Griffiths and Helen Tiffin, The Empire Writes Back: Theory and Practice in Post-Colonial Literatures (London: Routledge, 1989), pp. 7-8.

${ }^{38}$ Shirley Geok-lin Lim, Among the White Moonfaces, p. 104.

${ }^{39}$ Wong Phui Nam, Ways of Exile: Poems from the First Decade (London: Skoob Books Publishing, 1993), p. 140.

${ }^{40}$ In Monsoon History: Selected Poems, the title is changed to “To Li Po".

${ }^{41}$ Shirley Geok-lin Lim, Crossing the Peninsula and Other Poems, p. 92.

${ }^{42}$ Ibid., p. 93.

${ }^{43}$ Ibid., p. 49.

${ }^{44}$ Ibid., p. 49.

${ }^{45}$ Ibid., p. 73.

${ }^{46}$ Ibid., p. 73.

${ }^{47}$ Shirley Geok-lin Lim, Modern Secrets, p. 114

48 Shirley Geok-lin Lim, Writing South East / Asia in English: Against the Grain (London: Skoob Books Publishing, 1994), p. 39. 
49 Shirley Geok-lin Lim, What the Fortune Teller Didn't Say (Albuquerque: West End Press, 1998), p. 74.

${ }^{50}$ Ibid., p. 74.

${ }^{51}$ Shirley Geok-lin Lim, Crossing the Peninsula and Other Poems, p. 50.

52 Shirley Geok-lin Lim, Among the White Moonfaces, p. 240.

${ }^{53}$ Shirley Geok-lin Lim, Crossing the Peninsula and Other Poems, p. 82.

${ }^{54}$ Shirley Geok-lin Lim, No Man’s Grove, p. 63.

${ }^{55}$ Ibid., p. 48.

${ }^{56}$ Shirley Geok-lin Lim, Among the White Moonfaces, p. 240.

${ }^{57}$ Ibid., pp. 20-1.

${ }^{58}$ Shirley Geok-lin Lim, Writing South East / Asia in English: Against the Grain, p. 13.

${ }^{59}$ Shirley Geok-lin Lim, No Man’s Grove, p. 33.

${ }^{60}$ Shirley Geok-lin Lim, Among the White Moonfaces, p. 138.

${ }^{61}$ Shirley Geok-lin Lim, Writing South East / Asia in English: Against the Grain, pp. 145.

${ }^{62}$ Ibid., p. 31.

63 Ibid., p. 25.

${ }^{64}$ Hélène Cixous, 'The Laugh of the Medusa', in Robyn R. Warhol and Diane Price (eds.) Feminisms: An Anthology of Literary Theory and Criticism, 2nd ed, Keith Cohen and Paula Cohen (trans.) (New Brunswick, New Jersey: Rutgers University Press, 1997), p. 352.

${ }^{65}$ Homi K. Bhabha, The Location of Culture (London: Routledge, 1994), p. 1.

${ }^{66}$ Shirley Geok-lin Lim, Crossing the Peninsula and Other Poems, p. 53. 